\author{
Ewa Maria Romaniak \\ Cracow University of Technology \\ Faculty of Architecture \\ ul. Warszawska 24 \\ 31-155 Kraków \\ e.m.romaniak@gmail.com
}

\title{
CRICOTEKA - THEATRICAL DIMENSION OF ARCHITECTURE
}

\begin{abstract}
The paper concerns the analysis of the building of Cricoteka in terms of theatricality, which is the role of architecture in the performance of city life. It discusses such aspects as the transfer of the idea of theatre onto architectural form, the dialogue with the viewer, the place of the building in the city and the influence of the object on the environment by generating tension between individual elements of composition solids.

Theatrical dimension of architecture might be understood as a spectacle, invented and robust physiognomy, but also intriguing visual appeal. Through the versatile architectural costumes the architecture puts on, especially contemporary architecture, which stands out from the other buildings, tends to be incomprehensible to its recipients. Aiding the comprehension of the message, as well as its conscious shaping by the authors, is key to mutual understanding and establishing the dialogue. The detailed analysis of the building's interior, which is the key aim of a project of Cricoteka, remains out of scope of this work.
\end{abstract}

\section{Keywords:}

Cricoteka, transfer of the idea of theatre, theatrical dimension of architecture

\section{INTRODUCTION}

Cricoteka has been established in 1980, initially operating under the name Centre Cricot 2 to document the activities of Tadeusz Kantor in the world of art and theatre. After the death of the artist the name was changed to the Centre for Documentation of the Art of Tadeusz Kantor Cricoteka. ${ }^{1}$

\footnotetext{
${ }^{1}$ Natalia Zarzecka, "Archiwum Kantora - dzieło totalne," in Cricoteka - historia ośrodka i nowej siedziby, ed. Paulina Kaucz, Natalia Zarzecka (Kraków: Ośrodek Dokumentacji Sztuki Tadeusza Kantora-CRICOTEKA, 2015), 23, 29.
} 
For many years, the institution functioned in several places in Kraków (offices of Cricoteka at Szczepańska Street, Archive of Cricoteka at Kanonicza Street, Room - Workshop of Tadeusz Kantor at Sienna Street and warehouses of the works). There wasn't one place for full presentation of Tadeusz Kantor's works.

In 2005 the idea to create a new place for the institution was presented. The initial plans envisaged adaptation of the building of the former power station and integrating it with a modern building that would become the head office of Cricoteka. The building of the new Cricoteka was to adapt the historic building of the Podgórska Power Station at the Nadwiślańska Street in Cracow, which in turn is situated right next to Podolski Boulevard (see fig. 1). To bring this idea to realization, an international architectural competition was announced. As a result of this competition, a year later the concept proposed by IQ2 Konsorcjum, consisting of design studio Wizja - Stanisław Deńko and design studio nsMoonStudio - Piotr Nawara, Agnieszka Szultk, was chosen. The grand opening of the new Cricoteka took place on the $12^{\text {th }}$ of September $20144^{2}$ The building fulfills the multiple roles of a museum, archive, gallery and a theatre. It is a place where a new generation of creators and researchers will be able to experience art.

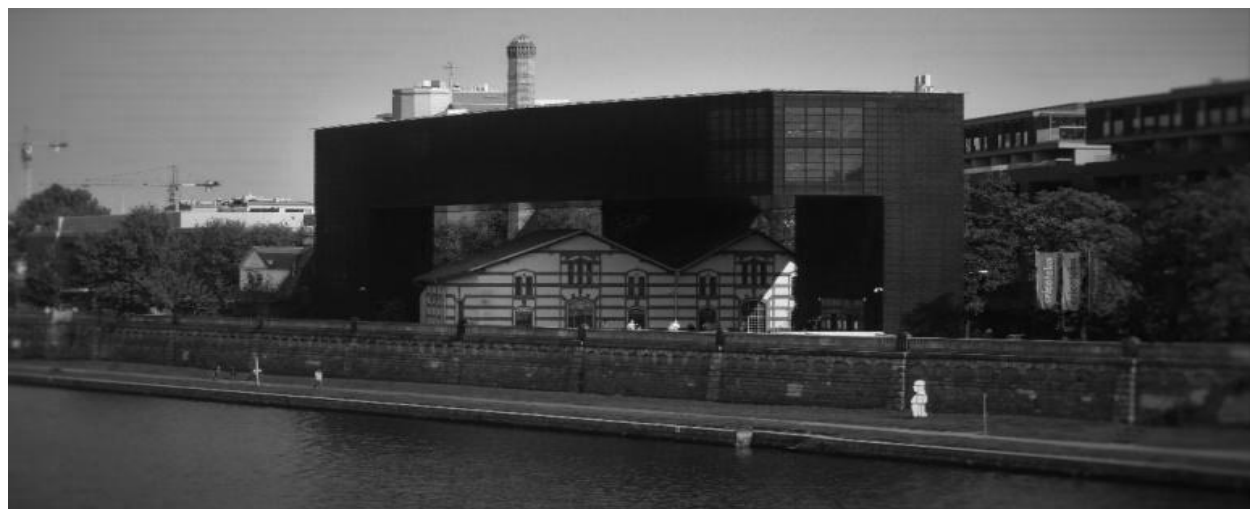

Fig. 1. View of the building Cricoteka from the footbridge Bernadka. Photo by Ewa M. Romaniak.

\section{TRANSFER OF THE IDEA OF THEATRE. ONTO ARCHITECTURAL FORM}

In case of Cricoteka, transforming of the theatrical idea into shape began with the very inspiration for the form of the building. The whole composition consists of two basic elements: old power plant and the new form, hanging over the first

\footnotetext{
${ }^{2}$ Ewa Dworzak-Żak, "Nowa Cricoteka w Krakowie - powiększony kantorowski rekwizyt," Budownictwo, Technologie, Architektura 4 (2014), 34.
} 
one like a bridge. In the visual reception, a specific frame that protects the antique interior is created and also a cropping of space takes place. The entirety brings the impossible figures to mind, which pertain to Kantor's creation of a series of black and white collages, picturing monumental objects with city panoramas in the background (e.g. a huge light bulb in the middle of a paved town square, a large hanger joining two riverbanks in Cracow like a bridge, a big chair). In this case, we have a bridge, a frame surrounding the square and a building of a former power plant. This new frame symbolically discloses the historical interior which in 1920 s used to play the role of a shelter for the homeless. In Kantor's art, in his concepts and performances, the figures of the homeless, tramps, and degraded reality played an important role. In the described composition of the spatial distribution of Cricoteka, this "discovered history" takes on an additional symbolic meaning.

The square becomes the main focus. Using strong contrasts was a deliberate action of the designers who aimed at creating a "spark" that would intrigue the viewers. ${ }^{3}$ The contrasts become apparent both in the composition and distribution of forms, applied materials, and in the context of juxtaposing them with the existing urban tissue.

A starting point for the form of the building was Kantor's sketch "Man carrying the table." "The man combined with the table gained a whole new meaning, just like the final form of Cricoteka's building. The structure of the antique power plant in combination with the new form took on a distinct character, both physically and symbolically. Through this juxtaposition, the contrasts were highlighted: new - old, simplicity - detail. The old building is entwined with the overarching new tissue consisting of a bridge-like construction. A sort of frame that was achieved in this way crops the view and creates an interesting composition in and of itself.

Another visible inspirations for the final form of the building were artistic forms used by Tadeusz Kantor in his works: assemblage and emballage, i.e. gathering together and combining various ready-made objects in a work, or wrapping other objects, for example buildings or fragments of landscape, so that they change their looks and meaning. They were subspatial compositions, in which the artist utilized used and often damaged objects, e.g. envelopes, umbrellas, bags. Those degraded objects gained thus a new life, took on a new meaning. ${ }^{5}$

\footnotetext{
${ }^{3}$ Stanisław Deńko, "Cricoteka," in Cricoteka - historia ośrodka i nowej siedziby, ed. Paulina Kaucz, Natalia Zarzecka (Kraków: Ośrodek Dokumentacji Sztuki Tadeusza Kantora CRICOTEKA, 2015), 14.

${ }^{4}$ Agnieszka Szultk, "Cricoteka," in Cricoteka - historia ośrodka i nowej siedziby, ed. Paulina Kaucz, Natalia Zarzecka (Kraków: Ośrodek Dokumentacji Sztuki Tadeusza Kantora CRICOTEKA, 2015), 105.

${ }^{5}$ See: Tadeusz Kantor, "Manifest Ambalaży," in Tadeusz Kantor. Metamorfozy. Teksty o latach 1938-1974, ed. Krzysztof Pleśniarowicz (Kraków: Księgarnia Akademicka, 2000), 333-334.
} 
The fact of joining into one functional structure a former power plant and a new, modern form can be considered a form of assemblage. The primary function of the power plant gained yet another life - new functions together with the new part. Additionally, the construction of the new part resembles the construction of a bridge which embraces the building of the power plant just like a foliage, which hides and blurs the sharpness of the form of the historical building, giving the whole a new quality. The effect of emballage was achieved in the elevation of the building, mostly covered in glass along with metal elements with specially designed cuts partly on the exterior. Those rust-colored elements at a distance create an impression of a single monolithic shape, which, due to its color, on the one hand fits in with the surrounding buildings of Podgórze, but still show distinction At a close range, on the elevation we can see details of openwork designs cut in the metal plates. At the same time, they allow to "peek" from the inside at the area around the building, as actors in the theatre would from behind the curtain (see fig. 2).
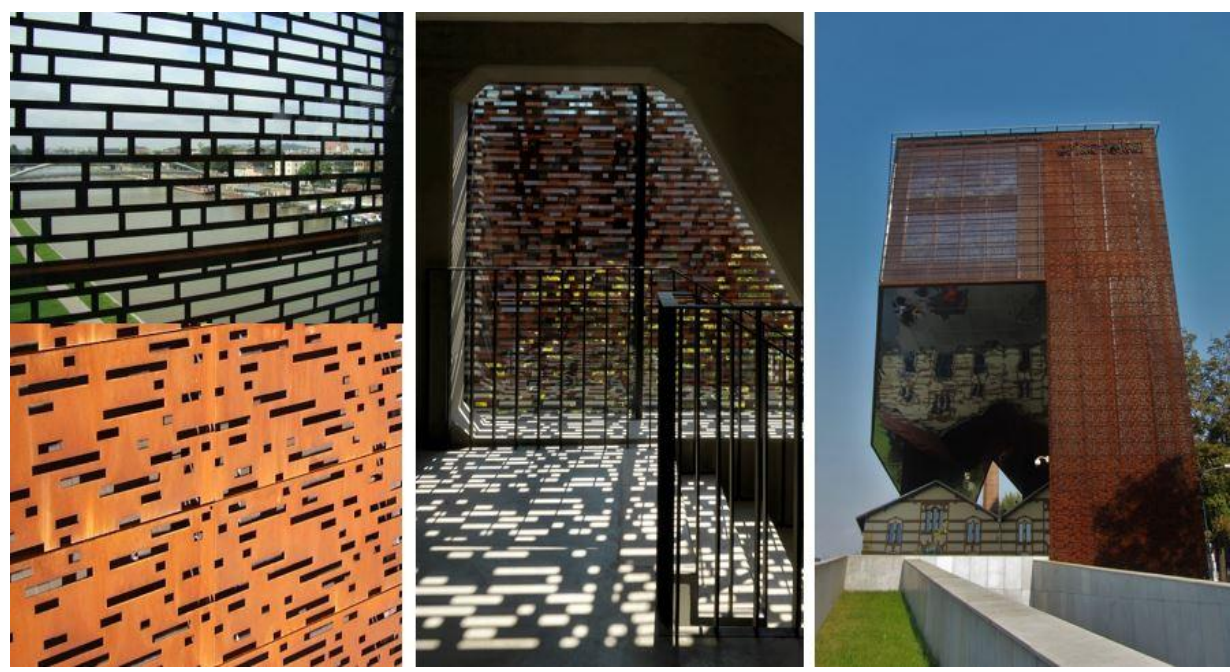

Fig. 2. Photos illustrating the material covering the facade. Turn: view from the inside on the detail; view from the outside on the detail (openwork pattern cutouts), view of the interior and the view of the facade from a distance. Photo by Ewa M. Romaniak.

\section{THE ROLE OF THE BUILDING IN THE AREA OF THE CITY}

Another important element is the role of the building in the space of the city. The building is situated between Zabłocie, where such places as Museum of Contemporary Art MOCAK, Emalia Oskar Schindler's Factory Museum and 
Glass and Ceramics Centre are located, and Wawel castle, St. Stanislaus Church at Skałka and International Conference and Entertainment - ICE. Close by, there is a bridge "Bernatka" that joins Podgórze with Kazimierz (see fig. 3 ).

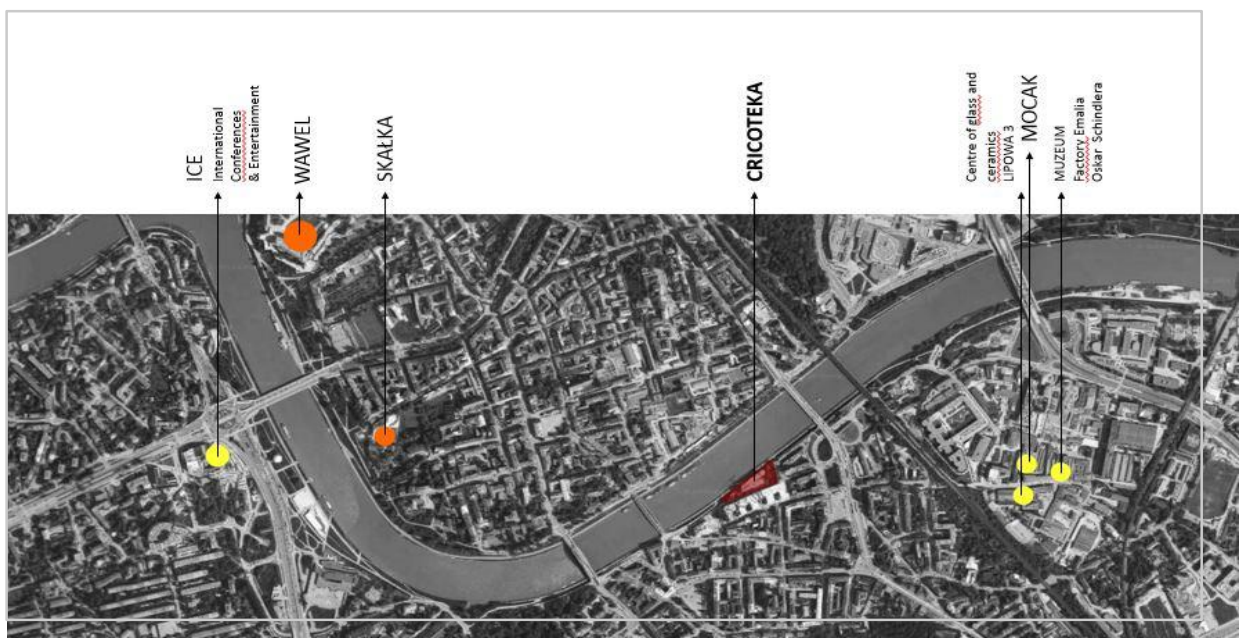

Fig. 3. The location of Cricoteka and other important objects on the map of Cracow. Photo by Ewa M. Romaniak.

As a result of this location, Cricoteka plays an important role in the space of the city, due to its placement at the intersection of traffic routes between three important areas. Such location of the building by the Vistula Boulevard also livens up the banks of Vistula River through its visual form. It serves as the

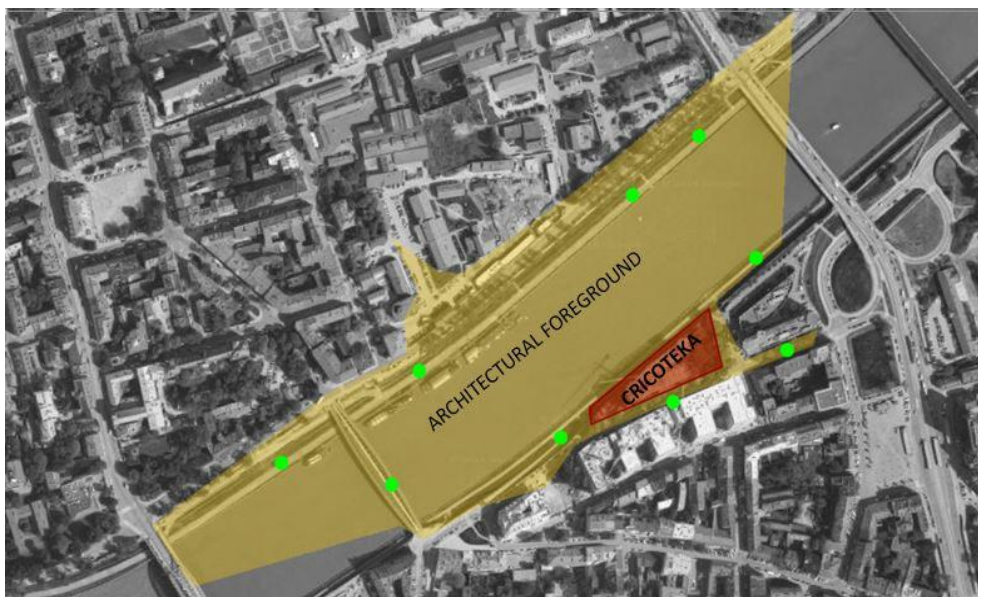

Fig. 4. A diagram illustrating the area of Cricoteka and its architectural foreground. Photo by Ewa M. Romaniak. 
dominant object while the space in direct visual area of influence of the building forms the architectural foreground. In this case, it is mainly the Vistula river along with its banks and, to a lesser degree, surrounding streets (see fig. 4).

By observing the building from various points of the boulevard on the other side of the river or bridge, its role in the panorama of the city and Vistula river embankment is revealed. By recalling an analogy to a theatre play - one can afford a statement that the building, just like an actor, plays its functional and aesthetic role on the stage of the city. The audience is the architectural foreground and the stage is the existing architectural tissue (see fig. 5, 6, 7, 8, 9). The original shape stands out in the urban landscape, becoming an architecture that publicly emphasizes its distinctness and cultural function.

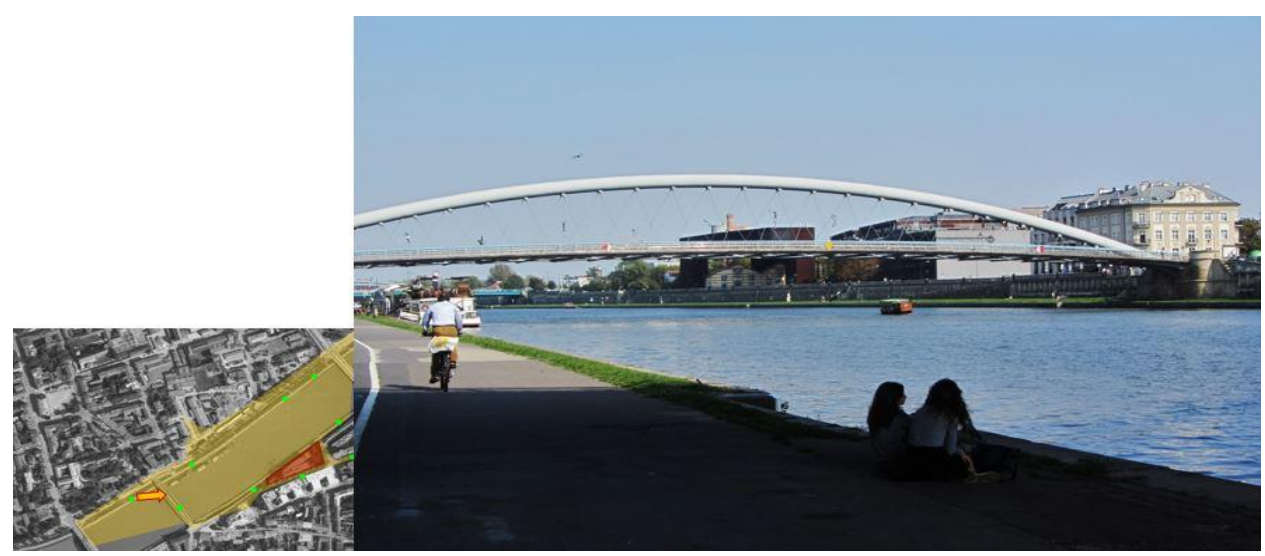

Fig. 5. View of the building Cricoteka from across the Vistula Boulevard. Photo by Ewa M. Romaniak.

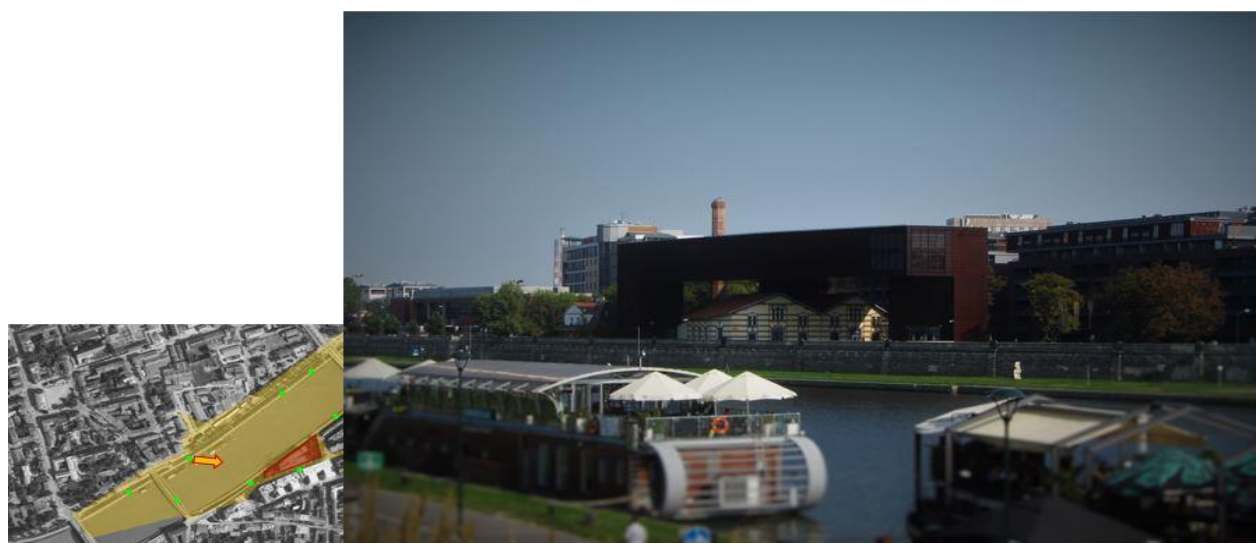

Fig.6. View of the building Cricoteka from across the Vistula Boulevard. Photo by Ewa M. Romaniak. 


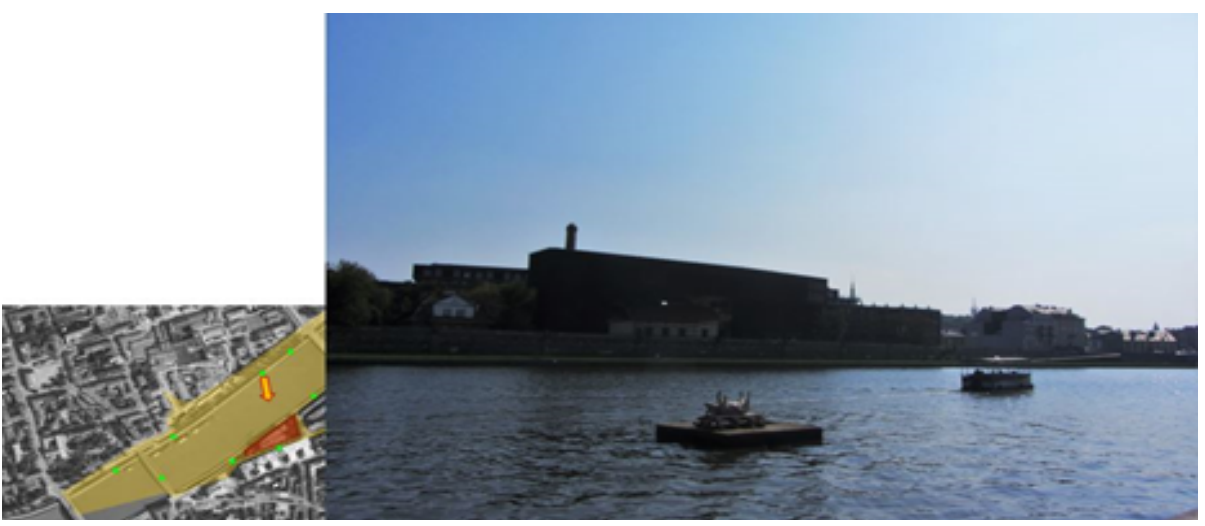

Fig. 7. View of the building Cricoteka from across the Vistula Boulevard. Photo by Ewa M. Romaniak.

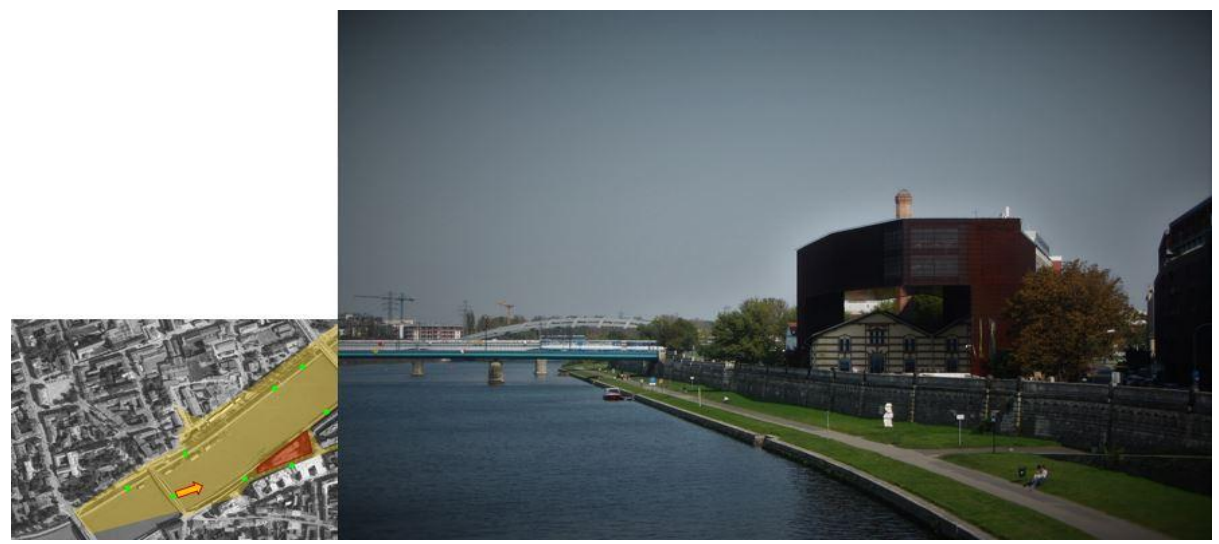

Fig. 8. View of the building Cricoteka from the footbridge Bernadka. Photo by Ewa M. Romaniak.

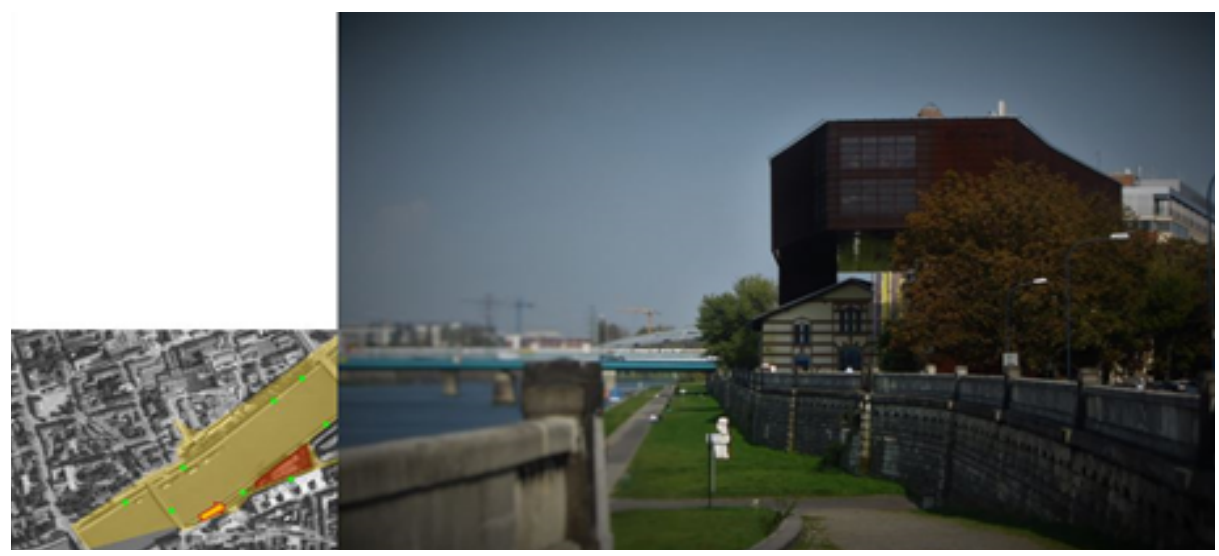

Fig. 9. View of the building Cricoteka from Podolski Boulevard. Photo by Ewa M. Romaniak. 


\section{PUBLIC SPACE AND ARCHITECTURAL FOREGROUND}

Another interesting element of the Cricoteka is the space of a public plaza created beneath the construction of the new part of the building hanging above. As a result, the plaza is in the centre of the whole concept. It has a sightseeing opening towards Vistula. It is both a scene where city life can play out and an auditory when one can observe the embankment and life of the city. Referring to the specifics of Kantor's "poor theatre," in his uniqueness, in comparison with other theatrical forms, one can find analogous elements, such as the directness of action or eliminating the barrier between the stage and the audience. An important element is the use of a tiles of polished steel in the structure of the building above the plaza, as a result of it a mirror-like effect was achieved (see fig. 10). From the level of the boulevard, a reflection of the plaza and the building of the old power plant can be observed, from the plaza - the plaza itself and the reflected boulevard can be seen (see fig. 11). The resulting reflections create shapes that bring Kantor's impossible forms to mind. A world of theatrical illusion is created, unreal, with multitude of possible interpretations.

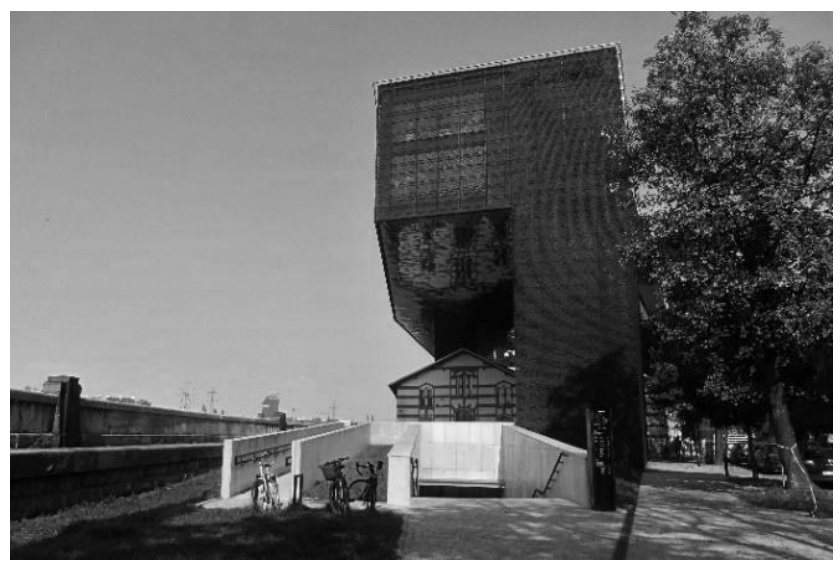

Fig. 10. View of the building of Cricoteka - entrance, steel structure of mirror above the plaza. Photo by Ewa M. Romaniak.

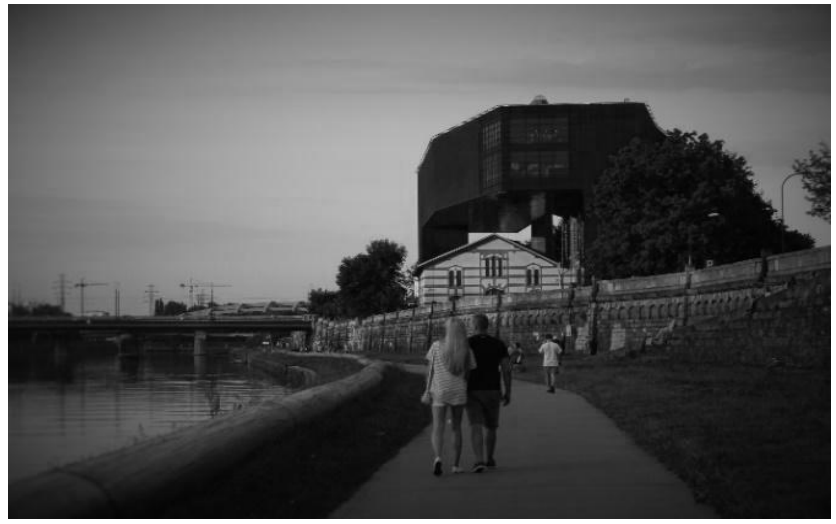

Fig. 11. View of the building of Cricoteka from Podolski Boulevard. Photo by Ewa M. Romaniak. 
ELEVATION - RELATIONS BEETWEN OUTSIDE AND INSIDE

The shell used as the external part of building's elevation is corten, which is a special type of steel resistant to weather conditions, with a characteristic color of rust. ${ }^{6}$ Tiles of steel form an openwork by being cut in a specially designed pattern. The resulting form separates the interior from the exterior (see fig. 2). The openwork can be interpreted as a coded message. In the words of one of designers Piotr Nawara: "The new Cricoteka - object that changes the physicality or visual aspect through a code written into its structure or functions taking place inside."7 The elevation of the building is both a specific "envelope" for Tadeusz Kantor's art (that being a nod to assemblage) and an architectural costume expressing certain message, dressing the actor - the building itself - along with his function and idea. It protects and invites, brings interest at the same time.

While perceived from the outside, it intrigues the viewer with its protective and aesthetic role. From the inside, we can see the world through openwork costume, which fulfils a different role depending on the time of day or night, the place from which it is observed and content that forms the context of the observation. The border is blurred, one can note the abolition of barriers so important in the concept of Kantor. Complementing the elevation is the illumination (fig. 12). Light is amplified by the reflections in the mirror on the building, as well as the reflections that appear on the water.

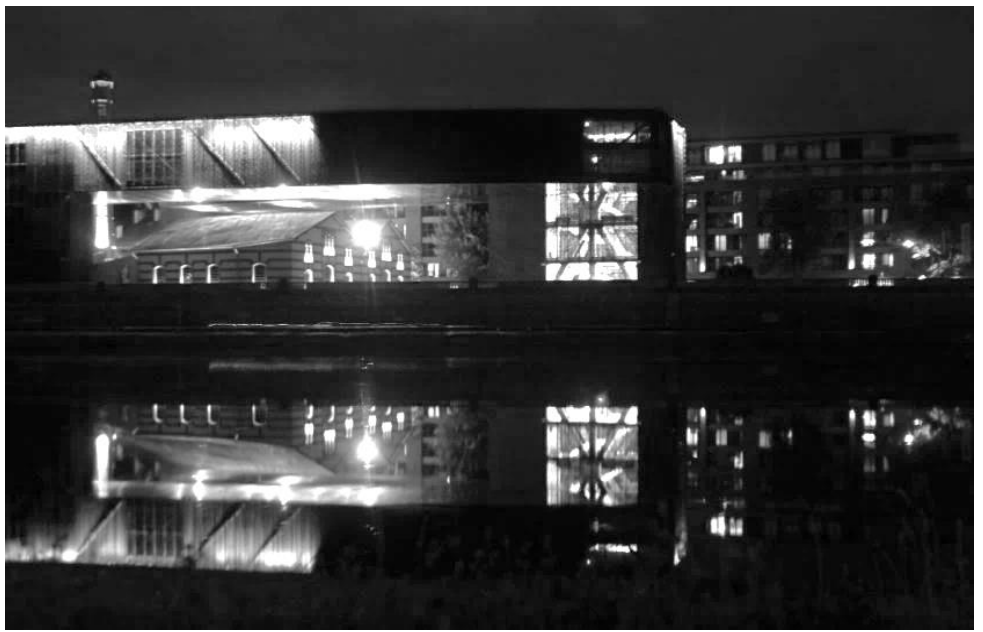

Fig. 12. The night illumination of the building. Photo by Ewa M. Romaniak.

\footnotetext{
${ }^{6}$ Dworzak-Żak, "Nowa Cricoteka w Krakowie - powiększony kantorowski rekwizyt," 37.

${ }^{7}$ Piotr Nawara, "Czy Cricoteka zmieni Kraków," in Cricoteka - historia ośrodka i nowej siedziby, ed. Paulina Kaucz, Natalia Zarzecka (Kraków: Ośrodek Dokumentacji Sztuki Tadeusza Kantora CRICOTEKA, 2015), 101.
} 


\section{IDEAS OF TADEUSZ KANTOR - A RECORD OF WORDS IN ARCHITECTURE}

Tadeusz Kantor had a well defined vision of Cricoteka. By reaching out to notes and texts of the artist himself we can find the materials regarding the creation and future functioning of the institution and then analyze the scale of the realization of the initial idea.

Obvious references to Kantor's statements can be found in the way the new building of Cricoteka is operating: "Creating Cricoteka requires an understanding that it would be establishment of an unprecedented, combining its shape and function: (1) visual sphere (exhibition, collection, reconstruction of stage situations); (2) research - archival (archive reading room); (3) teaching (lectures, studies, experimental atelier); (4) at the same time leaving space for lively artistic events." $"$

The artist stressed on numerous occasions the dual role of the center, both as a museum and scientific institute. Both of these functions are to be joined by the archive, which is the only guarantor of the continued existence of the creations of theatre Cricot 2, establishing them in the society's awareness and passing them to the future generation. ${ }^{9}$ In Kantor's texts we can find detailed information about the nature of museum's archive, its function and didactic role.

In another text we can find references to the "idea of journey in art". Kantor describes how Cricot 2 became a wandering theatre as a result of numerous invitations for performances abroad: "We conquered the world; not with a well known among us intention of foreign travel. My primary conviction was a postulate that art is international. We never sought those opportunities ourselves. The world itself strived for our arrival. Increasingly harder. Slowly, Cricot 2 became a wandering theatre (...)." ${ }^{10}$ In the context of these words, the building's construction that forms a "bridge" over the old power plant's building may be considered. In the "bridge's" interior an exhibition hall is located. It is an example of symbolic analogues. Bridge, like Theatre Cricot 2 via multiple abroad performances brought people closer despite their political differences, joined them through the message. Currently, the exhibition hall through the presentation of art - joins without regard to time, language and other differences. The journey motif is also present in the already mentioned sketch of

\footnotetext{
${ }^{8}$ Fragment of Tadeusz Kantor's text written at the turn of 1979 and 1980. Zarzecka, “Archiwum Kantora - dzieło totalne," 25.

${ }^{9}$ Krzysztof Pleśniarowicz, "Dzieło i komentarz Kantora - przenikanie granic,” in Tadeusz Kantor. Dalej już nic... Teksty z lat 1985-1990, vol. III, ed. Krzysztof Pleśniarowicz (Wrocław; Kraków: Ossolineum/Cricoteka, 2005), 317.

${ }^{10}$ Tadeusz Kantor, "Wstęp do biuletynu Teatru Cricot 2," in Tadeusz Kantor. Dalej już nic... Teksty z lat 1985-1990, vol. III, ed. Krzysztof Pleśniarowicz (Wrocław; Kraków: Ossolineum/Cricoteka, 2005), 322.
} 
a man carrying a table, which in turn served as an inspiration for the architects. A man - a traveler carrying a table - represents the idea of theatre as a means of dialogue. By assuming in the context of the shape of the building that the shape of the table was an archetype of the bridge-like form, which in turn functionally creates the space of the exhibition hall, we reach a symbolic message. In analogy to the sketch of a man - traveler, the building is carrying table-like structure - theatre - bridge - art as a modern means of dialogue.

Kantor also points out the importance of preserving memory, and concurrently creation of space that gives a possibility of future development: "(...) archives will remain - Cricoteka. They must remain. They, one day, will serve those who will want to build. (...) Remember the living archives of Theatre Cricot, remember Circoteka!" 11 The new building fits into this idea starting from the functions of the interior (the changing exposition, exhibitions of contemporary artists, theatre stage) through the educational functions to the creation of a public space available to everyone.

\section{INTERIORS}

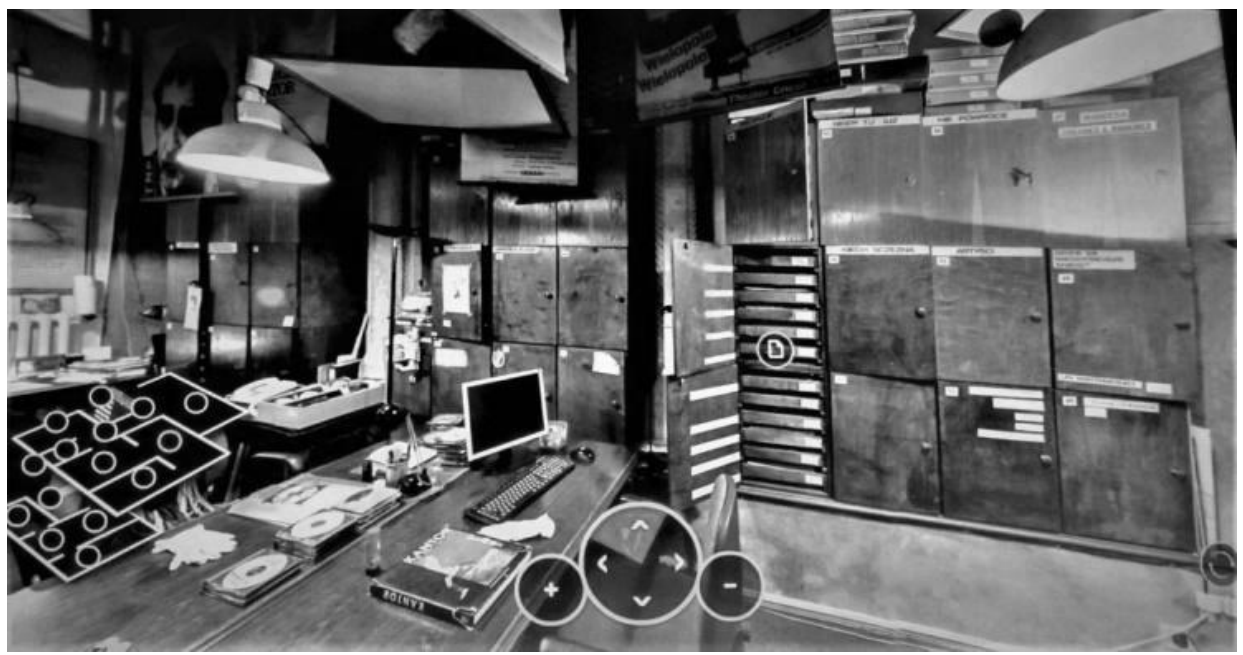

Fig. 15. The interior of the old archives of Cricoteka. Photo form the Cricoteka archives.

An integral complement of the whole are the interiors of the building, capacious exhibition spaces and their furnishings. The space was designed in such a way as to fulfill the role of the background for the expositions or events. The walls are

${ }^{11}$ Tadeusz Kantor, “Twórca: konieczność przekazywania," in Tadeusz Kantor. Dalej już nic... Teksty z lat 1985-1990, vol. III, ed. Krzysztof Pleśniarowicz (Wrocław; Kraków: Ossolineum/Cricoteka, 2005), 327-328. 
smooth and uniformly covered in white. In some of them, bricks appear. The necessary installations are covered in black metal nets forming a suspended ceiling. Details of finishings, like railings, were also made of black metal in a very simple form.

The furniture is in part originally designed by Tadeusz Kantor himself or used by him in the first archive. Among those are special bookstands with shelves to segregate the documents (see fig. 13). In the interiors of the new archive we can find the framed posters that filled the former space (see fig. 14, 15).

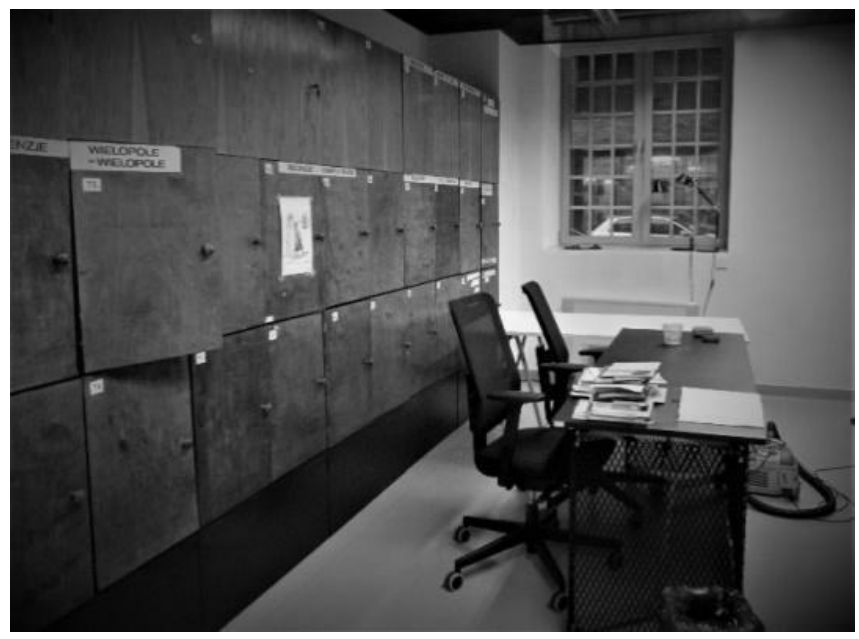

Fig. 13. Archive cabinets designed by Tadeusz Kantor in new Cricoteka building space. Photo by Ewa M. Romaniak.

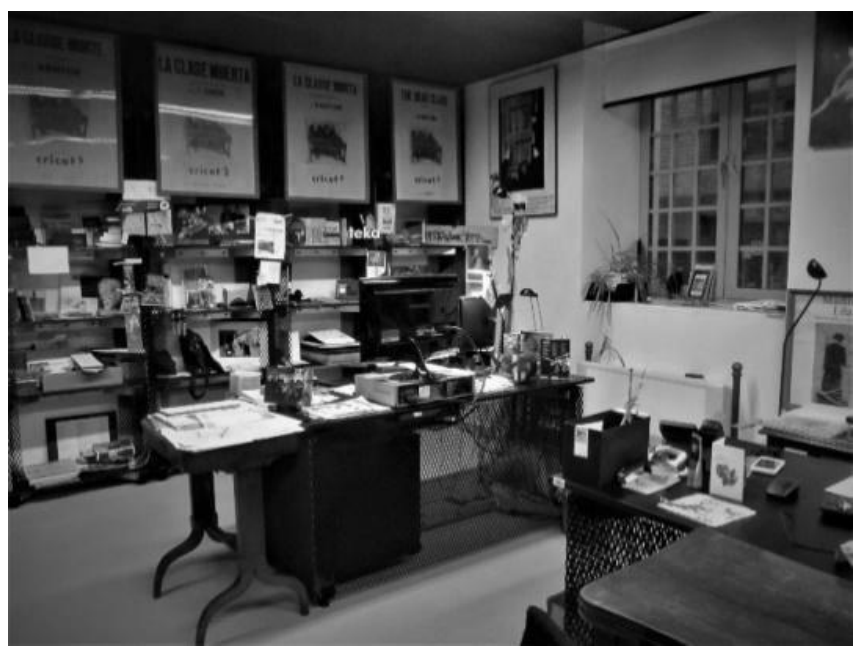

Fig. 14. Interior one of the rooms in the new building with original furnishings moved from the former Cricoteka archives. Photo by Ewa M. Romaniak.

The archive in its new headquarters references the mood of the original archive by means of using the furnishings and ornaments brought over from the Sienna Street location. 
The interior of Kantor's workshop remains important, by the artist's will it was made available for visitors after his death and is located at Sienna Street in Cracow and know as "Cricoteka's annex." 12 The workshop, the "unique kind of individual place, preserved as a testament to the conditions where the concepts of the last spectacle, numerous last paintings and last writings were created." ${ }^{\prime \prime}$

\section{CONCLUSIONS}

The analogies between the form of Cricoteka's building and Kantor's creation are visible in the concept of the "poor theatre" and his separateness from the other theatrical concepts. In Kantor's theatre, the least important objects of everyday use played crucial parts. The translation of this idea into the language of architecture is visible in the adaptation of the building of a former power plant which after it ceased operating served as a municipal dormitory and bath house for the homeless. The rust covering the material applied on the elevation (corten) is seemingly the materials of the lowest rank, but through its aesthetics it merges the block into a coherent unity and makes it stand out from the urban landscape.

The building acts in the urban space analogous to the actor on stage. The following scenes are built with the use of means like form, light, variability over time, cropping. Simultaneously, the boundaries between the stage and the audience become blurred through the inner public square. These actions serve to draw the audience that is within their range to a common play. Thus created space aids all kinds of happenings. The architectural spectacle continues incessantly through the reflections, illuminations, and openness of the space of the inner square.

The elevation plays the role of an architectural costume, which is an integral part of the coded message. It becomes a mask blurring the inner shape. It's an element of an emballage used so frequently in Kantor's works.

Independently of the first plan and inspirations on part of the designers, apart from the obvious function as an archive, exhibition and experimental place for future generations of creators, the building entails the coded ideas of Tadeusz Kantor's creation. One of them is elevating the meaning of used objects, as well as assigning a new function to the power plant building and later the shelter for the homeless. It is the creation in various aspects an impossible block, which becomes visible in the form of the building as opposed to the other buildings.

\footnotetext{
${ }^{12}$ Natalia Zarzecka, "Galeria - pracownia Tadeusza Kantora," in: Cricoteka - historia ośrodka i nowej siedziby, ed. Ewa Ryżewska (Kraków: Ośrodek Dokumentacji Sztuki Tadeusza Kantora - CRICOTEKA, 2009), 43.

${ }^{13}$ Tadeusz Kantor, "Regulamin pracowni," in Tadeusz Kantor. Dalej już nic... Teksty z lat 1985 1990, vol. III, ed. Krzysztof Pleśniarowicz (Wrocław; Kraków: Ossolineum/Cricoteka, 2005), 325.
} 
The shown contrasts in the form and aesthetics highlight the uniqueness of the object, intrigue the audience as part of the urban landscape. The architecture affects the audience, draws them to the interior "packed" in rust, encourages discussion and stresses its own uniqueness and cultural function.

The analyzed arguments and analogies to the creation of Tadeusz Kantor are results of observations which didn't have to be called out consciously and inscribed in the architectural form, but are possible to read. If these encoded elements are partly the result of pure coincidence, it would be a thing worth considering - to consciously shape similar buildings in the future.

\section{BIBLIOGRAPHY}

Deńko, Stanisław. "Muzeum Kantora w Krakowie.” Architektura, 7 (2013): 14-18.

—. "Cricoteka." In Cricoteka - historia ośrodka i nowej siedziby, edited by Paulina Kaucz, Natalia Zarzecka, 95-100. Kraków: Ośrodek Dokumentacji Sztuki Tadeusza Kantora CRICOTEKA, 2015.

Domicz, Antoni. "Wieloznaczna rzeźba." Architektura \& Biznes 10 (2014): 34.

Dworzak-Żak, Ewa. "Nowa Cricoteka w Krakowie - powiększony kantorowski rekwizyt." Budownictwo, Technologie, Architektura 4 (2014): 34-37.

Kantor, Tadeusz. "Cricoteca." In Cricoteca - wystawa $w$ Bibliotece Narodowe edited by Agnieszka Konopka, 5-6. Warszawa: Biblioteka Narodowa, 2005.

—. "Regulamin pracowni." In Tadeusz Kantor. Pisma. Dalej już nic... Teksty z lat 19851990, vol. 3, edited by Krzysztof Pleśniarowicz. Wrocław; Kraków: Ossolineum/Cricoteka, 2005.

."Twórca: konieczność przekazywania.” In Tadeusz Kantor. Pisma. Dalej już nic... Teksty $z$ lat 1985-1990, vol. 3, edited by Krzysztof Pleśniarowicz, Wrocław; Kraków: Ossolineum/Cricoteka, 2005.

—. "Wstęp do biuletynu Teatru Cricot 2." In Tadeusz Kantor. Pisma. Dalej już nic... Teksty $z$ lat 1985-1990, vol. 3, edited by Krzysztof Pleśniarowicz. Wrocław; Kraków: Ossolineum/Cricoteka, 2005.

Nawara, Piotr. "Czy Cricoteka zmieni Kraków.” In Cricoteka - historia ośrodka i nowej siedziby edited by Paulina Kaucz, Natalia Zarzecka. Kraków: Ośrodek Dokumentacji Sztuki Tadeusza Kantora - Cricoteka, 2015.

Pleśniarowicz, Krzysztof . "Dzieło i komentarz Kantora - przenikanie granic.” In Tadeusz Kantor. Pisma. Dalej już nic... Teksty z lat 1985-1990, vol. 3, edited by Krzysztof Pleśniarowicz. Wrocław; Kraków: Ossolineum/Cricoteka, 2005.

Szultk, Agnieszka. "Cricoteka." In Cricoteka - historia ośrodka i nowej siedziby, edited by Paulina Kaucz, Natalia Zarzecka. Kraków: Ośrodek Dokumentacji Sztuki Tadeusza Kantora - Cricoteka, 2015.

Zarzecka, Natalia. "Galeria - pracownia Tadeusza Kantora." In Cricoteka - historia ośrodka i nowej siedziby, edited by Ewa Ryżewska. Kraków: Ośrodek Dokumentacji Sztuki Tadeusza Kantora - Cricoteka, 2009.

—. "Archiwum Kantora - dzieło totalne.” In Cricoteka - historia ośrodka i nowej siedziby edited by Paulina Kaucz, Natalia Zarzecka. Kraków: Ośrodek Dokumentacji Sztuki Tadeusza Kantora - Cricoteka, 2015. 